ROCZNIKI PEDAGOGICZNE

Tom 11(47), numer 2 - 2019

DOI: http://dx.doi.org/10.18290/rped.2019.11.2-4

KS. ADAM MAJ

\title{
DUCHOWOŚĆ W INTEGRALNEJ EDUKACJI WCZESNOSZKOLNEJ
}

Duchowość jest kategorią istotnie opisującą naturę i egzystencję człowieka, jego najgłębszą i rzeczywistą teorię życia, implikującą całokształt postaw i czynów. Stanowi przedmiot zainteresowania wielu nauk, przede wszystkim teologii i filozofii, zwłaszcza w aspekcie antropologicznym, a także psychologii, socjologii i pedagogiki. Niegdyś związana, a nawet utożsamiana tylko z religijnością (i ten nurt nadal pozostaje aktualny), współcześnie zawdzięcza szerokie zainteresowanie postrzeganiu jej w perspektywie naturalistycznej i powiązaniu z ogólnie rozumianą kondycją człowieka, jego dobrostanem psycho-zdrowotnym, podkreślanym na przykład przez Światową Organizację Zdrowia.

$\mathrm{W}$ aspekcie pedagogicznym duchowość stanowi element kluczowy praktyki wychowawczej i przedmiot naukowej refleksji. Wychowanie jako inspirowanie rozwoju wychowanka ku pełni jego człowieczeństwa w ostatecznym wymiarze wiąże się z rozwojem jego duchowości. W pedagogice, zwłaszcza personalistycznej, kształt tak rozumianego wychowania określają pojęcia: ,integralny rozwój”, „,integralne wychowanie”, obejmujące całość osoby wychowanka i jego ludzki potencjał. Z tej perspektywy integralny rozwój i wychowanie mają towarzyszyć człowiekowi na wszystkich etapach jego życia.

Przedmiotem proponowanej analizy jest okres dzieciństwa, określany jako młodszy szkolny, rozpatrywany w aspekcie edukacji wczesnoszkolnej. Ze względów programowych i praktyki edukacyjnej ten pierwszy etap szkolny nazywany jest kształceniem zintegrowanym. Stąd powstają pytania: jaka jest czy powinna być relacja pomiędzy integralnym rozwojem i wychowaniem dziecka/ucznia a zintegrowaną edukacją wczesnoszkolną; jakie jest, czy powinno być znaczenie

Ks. dr hab. ADAm MAJ, prof. KUL - Katedra Dydaktyki i Edukacji Szkolnej, Instytut Pedagogiki KUL, Lublin; e-mail: adammaj@kul.pl 
duchowości w integralnej edukacji wczesnoszkolnej? Oba pytania są ze sobą związane, ale drugie stanowi właściwy problem badawczy prezentowanego opracowania, podejmowanego metodą analizy dokumentów i analityczno-syntetyczną, stanowiąc jedynie przyczynek do pogłębionych badań teoretyczno-empirycznych, jakie powinny objąć ten obszar rzeczywistości edukacyjnej.

\section{WCZESNOSZKOLNA EDUKACJA I JEJ INTEGRALNY WYMIAR}

Pojęcie edukacji wczesnoszkolnej implikuje rozumienie istoty edukacji oraz konieczność określenia pierwszego, wczesnego etapu szkolnego. Edukacja jest terminem najszerszym i najbardziej ogólnym, obejmującym wszelkie oddziaływania na rozwój i formowanie się człowieka (celowe i niecelowe, świadome i nieświadome). W systemie szkolnym edukacja jest zespołem oddziaływań świadomych i zamierzonych, programowych, służących ukształtowaniu postaw i systemu wartości ucznia (wychowanie) oraz jego wiedzy i umiejętności (kształcenie, dydaktyka - nauczanie i uczenie się). Na pojęcie edukacji składa się zatem wychowanie i kształcenie, a proces edukacyjny w szkole należy rozumieć jako dydaktyczno-wychowawczy (Milerski, Śliwerski, 2000, s. 54).

Natomiast określenie edukacji jako wczesnoszkolnej wskazuje na pierwszy szczebel kształcenia ogólnego dzieci w przedziale wiekowym od 7 do 10 lat, obejmujący 3 lata nauki w klasach I-III szkoły podstawowej. Na tym etapie edukacji zajęcia szkolne są prowadzone przez jednego nauczyciela, który pełni także funkcję wychowawcy. To stopniowe przechodzenie od okazjonalnej nauki do uczenia się w sposób świadomy - pod kierunkiem kompetentnego pedagoga.

Zgodnie z myślą pedagogiczną i wymogami prawnymi w szkole podstawowej na pierwszym etapie, wczesnoszkolnym, edukacja realizowana jest $\mathrm{w}$ formie kształcenia zintegrowanego (Karbowniczek, Klim-Klimaszewska, 2016). Ten typ kształcenia związany jest z fazą rozwojową uczniów, postrzeganiem przez nich świata i sposobami nabywania nowej wiedzy i umiejętności. Kształcenie zintegrowane - zdaniem B. Murawskiej - można rozumieć jako proces łączenia tego, co jest w szkole podzielone (np. czas zajęć, wiedza podzielona na przedmioty), po drugie jako proces wiązania wiedzy osobistej uczniów $\mathrm{z}$ wiedzą zdobywaną w szkole, po trzecie jako ,poszukiwanie nadrzędnej zasady scalającej w psychologiczną całość różne działania uczniów" (Murawska, 2014, s. 31), po czwarte jako korelację wiedzy z różnych dziedzin albo w ramach jednej dziedziny. 
Również prawo oświatowe w zakresie podstawy programowej określa kształcenie na etapie wczesnoszkolnym jako zintegrowane. Określenie istoty kształcenia zintegrowanego zawarte jest we wprowadzeniu do treści nauczania wczesnoszkolnego, gdzie stwierdza się, że ,proces kształcenia na tym etapie ma charakter zintegrowany, a nie przedmiotowy" (Podstawa programowa, 2017, s. 34 w Dz. U.), mimo przyporządkowania efektów kształcenia poszczególnym dyscyplinom wiedzy. Podkreśla się, że ten sposób prezentacji efektów jest tylko umowny, służący przejrzystości opisu osiągnięć i nie stanowi normy organizacyjnej. Wskazane w dalszej części dokumentu warunki realizacji procesu edukacji wczesnoszkolnej potwierdzają, że prawodawca ma na uwadze kształcenie zintegrowane w zakresie programu nauczania, przestrzeni i czasu zajęć oraz obejmuje „integrację czynnościową, metodyczną, organizacyjną i treściową" (tamże, s. 53 w Dz. U.). Celem kształcenia zintegrowanego na wczesnoszkolnym etapie jest ukazać „uczniom scalony obraz świata i ułatwić jego rozumienie” (tamże), natomiast nadrzędny cel edukacji wczesnoszkolnej stanowi „wspieranie całościowego rozwoju dziecka" (tamże, s. 16 w Dz. U.), który w wymaganiach ogólnych odniesiono do efektów w czterech obszarach rozwojowych: fizycznym, emocjonalnym, społecznym i poznawczym.

Konstrukcja podstawy programowej jest zasadniczo spójna i logiczna, chociaż budząca wątpliwości. Wymagania szczegółowe, w których zawarto efekty kształcenia $\mathrm{w}$ trzynastu modułach edukacyjnych, wydają się być bogatsze treściowo (zwłaszcza, gdy uwzględni się religię) niż wskazane obszary rozwojowe ucznia we wczesnoszkolnej edukacji. Wątpliwość wiąże się z wizją ucznia - człowieka. Czy tylko cztery obszary (fizyczny, emocjonalny, społeczny i poznawczy) charakteryzują człowieka, stanowiąc jego całość i pełnię? W pedagogice personalistycznej (czy tylko w niej?) eksponuje się koncepcję człowieka jako osoby i jego wielowymiarowe sfery: fizyczną, psychiczną, społeczną, kulturową i duchową (światopoglądową). Jej twórca na gruncie naukowej pedagogiki, S. Kunowski, do procesów rozwoju i wychowania osoby ludzkiej w powyższych warstwach używa określenia „,integralny”, podkreślając potrzebę harmonijnego rozwoju wszystkich sfer i konieczność odpowiedniego wspierania tego rozwoju przez działania wychowawcze. Integralny rozwój i wychowanie nie jest synonimem terminu ,kształcenie zintegrowane”. W praktyce pedagogicznej zintegrowane kształcenie powinno wspierać integralny rozwój ucznia jako rzeczywiście całościowy i pełny. W podstawie programowej, oprócz klarownej wizji ucznia jako człowieka - osoby, brakuje wyeksponowania wymiaru duchowego, bowiem elementy innych sfer rozwojowych człowieka znajdują się w różnych częściach 
podstawy programowej, szczególnie w modułach edukacyjnych. Stawiamy zatem pytanie, czym jest duchowość w perspektywie integralnego rozwoju i wychowania człowieka?

\section{DUCHOWOŚĆ W INTEGRALNYM ROZWOJU I WYCHOWANIU}

Jak już podkreślono, integralny rozwój polega na całościowym, harmonijnym, pełnym, spójnym rozwoju pięciu warstw (warstwic, sfer) człowieka: fizycznej, psychicznej, społecznej, kulturowej, światopoglądowo-duchowej (Chałas, 2007, s. 11; Rynio, 2004, s. 448). Dojrzały rozwój w każdej z poszczególnych warstw osoby ludzkiej decyduje o dojrzałości całego człowieka (Kunowski, 2004, s. 197). Dlatego wspomaganie rozwoju wszystkich warstw bytu ludzkiego warunkuje jego pełną i integralną progresję. Tym adekwatnym wspomaganiem jest wychowanie integralne.

Wychowanie integralne „obejmuje struktury procesu wychowawczego, rozumianego integralnie jako pewien byt jednolity, którego nie da się sprowadzić do funkcjonowania jedynie poszczególnych elementów" (Nowak, 2008, s. 132). Wychowanie skupia się na człowieku, który jest jego podmiotem, na jego stałym doskonaleniu. Polega na wspieraniu ,wychowanka w drodze do osiągnięcia pełni człowieczeństwa - w harmonijnym rozwoju swych potencjalności tkwiących w poszczególnych sferach: fizycznej, psychicznej, społecznej, kulturowej, duchowej, religijnej oraz ich integrowaniu ze sobą" (Chałas, 2007, s. 11). Stąd Jan Paweł II określa wychowanie „obdarzaniem człowieczeństwem - obdarzaniem dwustronnym" (1994, nr 16).

Dlatego zrozumiały jest nadrzędny cel szkoły, interpretowany w pedagogice personalistycznej jako integralny rozwój ucznia ukierunkowany na pełnię jego człowieczeństwa. Proces ten uwarunkowany jest wychowaniem integralnym, stymulującym rozwój wszystkich warstw osoby wychowanka, dojrzewających w swoim czasie i w uporządkowanej kolejności, począwszy od warstwy fizycznej do światopoglądowo-duchowej. Rozwój ten zaczyna się od dzieciństwa (Marszałek, 2013) i obejmuje również dzieci w wieku wczesnoszkolnym. Dlatego szkolna edukacja na pierwszym etapie powinna uwzględniać rozwój ucznia w zakresie fizycznym, psychicznym (intelektualnym, emocjonalnym, wolicjonalnym), społecznym, kulturowym i duchowym.

Zgodnie z podjętą problematyką uwagę zwraca sfera duchowa w integralnym rozwoju, decydująca o duchowości wychowanka. 
Duchowość (łac. spiritualitas) jest pojęciem wieloznacznym, które nie występuje w Piśmie św., ale znane jest w nauczaniu Kościoła, w teologii i filozofii już od V w., mając znaczenie religijne jako życie duchowe wzbudzone przez „Ducha Świętego działającego w człowieku” (Chmielewski, 2002, s. 226). Termin ten różnorodnie interpretowany w teologii, filozofii, a nawet zapomniany, powraca do użytku pod koniec XIX wieku. W ujęciu religijnym duchowość to „praktyka życia duchowego (sens subiektywny) i systematyczna refleksja nad tymże życiem duchowym (sens obiektywny)" (tamże, s. 228). W chrześcijańskiej interpretacji duchowość jest formą życia duchowego osoby przyjmującej Boże Objawienie w Jezusie Chrystusie, obejmującą nie tylko doświadczenie wewnętrzne, lecz także zachowania zewnętrzne (Jusiak, 2016, s. 284-285). Jeszcze bardziej szczegółowo określa duchowość W. Słomka, stwierdzając, że to określony styl życia: według Ducha Świętego, to postepowanie według Ducha Świętego, to zespół postaw (element intelektualno-poznawczy, emocjonalno-wartościujący, behawioralny), a także przekonań, motywacji, decyzji ,serc pobudzonych przez Ducha" (Chmielewski, 2002, s. 229). Przytaczając poglądy wspomnianego autora, M. Chmielewski stwierdza, że duchowość danej osoby to „zespół czy kształt postaw wobec tego, co obiektywne, lub subiektywnie uznawane jest za wartość" (tamże). W takim ujęciu duchowość jawi się jako nie tylko chrześcijańska, lecz także naturalna czy duchowość innych religii. Jej uniwersalny charakter stanowi właściwość osobową człowieka.

Nadprzyrodzony lub naturalistyczny wymiar duchowości dziś charakteryzuje różnorodne stanowiska teologiczne, filozoficzne czy psychologiczne. Oddziałuje także na pedagogikę teoretyczną i praktykę pedagogiczną w zakresie celów, treści, form i środków wychowywania. Problem duchowości rzutuje na koncepcję człowieka, stanowiącego podmiot działalności wychowawczej. W religijnej perspektywie można przyjąć wymiar fizyczny, psychiczny i duchowy człowieka, z założeniem V. Frankla, że duchowy wymiar nie jest redukowany do psychicznego. Ale zdarza się niejednokrotnie, że duchowość postrzegana jest w sposób naturalistyczny, nawet w nurtach pedagogiki i psychologii zorientowanej humanistycznie czy personalistycznie, ale nie inspirowanych poglądami teistycznymi, chrześcijańskimi. Duchowość interpretowana naturalistycznie osadzona jest w strukturze biologicznej człowieka jako ontycznej podstawie ludzkiej psychiki i jej szczególnej formy, którą stanowi duchowość.

Charakteryzując duchowość integralną - naturalną i nadprzyrodzoną, S. Kunowski wskazuje na takie jej cechy, jak: rozumność, zdolność do wartościowania i oceniania, wolność, twórczość, otwartość na głębię metafizyczną (2004, s. 189-190). 
Powyższe cechy wynikają z tożsamości bytowej człowieka, jej konstrukcji, umożliwiającej przekraczanie granic zmysłowego doświadczenia (transcendencja) i sięgania „aż do poznania źródeł bytu, do Absolutu i Boga” (Buk-Cegiełka, 2013, s. 60). Duchowość, jako najwyższa sfera, rozwija się - zdaniem S. Kunowskiego - poprzez głębsze przeżycia światopoglądowe, czyli: „Pytania poznawcze, teologiczne, wynikające z natury człowieka mądrego, zaczynają docierać do problemu źródeł bytu, jego początku i końca, genezy i celu świata i życia” (2004, s. 213).

$\mathrm{Na}$ podstawie różnorodnych analiz istoty duchowości można wyróżnić jej specyficzne elementy, do których należy transcendencja rozumiana jako przekraczanie własnej osoby, tego, co aktualnie doświadczane, co materialne, cielesne i przemijające. Kolejnym elementem duchowości jest poczucie sensu życia. Eksponuje go V. Frankl w swojej koncepcji logoteorii. Poczucie sensu życia istotnie wiąże się $\mathrm{z}$ aksjologicznym zaangażowaniem człowieka, społecznym i kulturowym, z realizacją indywidualnego sposobu życia i własnej egzystencji (Popielski, 2004). Zdaniem P. Sochy z duchowością powiązane są również takie kategorie, jak: świadomość i samoświadomość; rozum i mądrość; uczucia, zwłaszcza miłość; wrażliwość; moralność; twórczość; poczucie estetyczne; światopogląd; religijność; wiara (2000, s. 16-33).

Opis istoty duchowości i jej różnorodnego rozumienia odsłania doniosłe znaczenie duchowości w życiu ludzkim, wskazując na to, co rzeczywiście stanowi dla człowieka najwyższą, ostateczną wartość, jaką jest jego jednocząca filozofia życia. Dlatego nie można pomijać na jakimkolwiek etapie edukacji i w jakimkolwiek środowisku wychowawczym rozwoju duchowości wychowanka.

\section{DUCHOWOŚĆ W PROCESIE WCZESNOSZKOLNEJ EDUKACJI}

Wczesnoszkolna edukacja, jako proces całościowego (podstawa programowa), integralnego (pedagogika personalistyczna) rozwoju i wychowania ucznia, powinna wyraźnie uwzględniać rozwój jego duchowości. Jednak powstaje pytanie: o jakiego typu duchowość chodzi, naturalistyczną czy religijną? Respektując uniwersalną misję szkoły publicznej, trzeba stwierdzić w odpowiedzi, że powinien być taki typ duchowości, który z jednej strony nie będzie miał charakteru ewangelizacyjnego (religijnego), z drugiej strony ateizującego. Podstawowym kryterium wyboru specyfiki duchowości pozostaje uczeń z jego aktualną duchowością, kształtowaną w środowisku rodzinnym. Uczeń - osoba ludzka, jest w centrum procesu edukacji, dla niego jest szkoła, dla niego programy kształcenia i wychowania, dla niego wszelkie działania opiekuńcze i profilaktyczne. Zadania 
szkoły mają zatem koncentrować się na wspieraniu jego integralnego rozwoju, na korekcie wad, błędów, uproszczeń, przyczyniając się do maksymalnej progresji potencjału tkwiącego w jego człowieczeństwie, w różnych sferach, w tym przede wszystkim w sferze jego duchowości. Wydaje się, że w praktyce edukacyjnej, także wczesnoszkolnej, można skorzystać z ujęcia problematyki duchowości, które przedstawia S. Kunowski, zwanego wcześniej integralnym, łączącego aspekt naturalny i nadprzyrodzony. Według autora elementami duchowości są; rozumność, zdolność do wartościowania i oceniania, wolność, twórczość, otwartość na głębię metafizyczną. W propozycji P. Sochy pojawia się dodatkowo świadomość i samoświadomość, uczucia (miłość), wrażliwość, poczucie estetyczne oraz światopogląd, religijność i wiara, które mogą być włączone w kategorię otwartości na głębię metafizyczną - w interpretacji S. Kunowskiego. W odniesieniu do dzieci w wieku przedszkolnym i na użytek pedagogiki przedszkolnej, L. Marszałek przyjmuje koncepcję P. Sochy z modyfikacjami uzasadnionymi stadium rozwoju dzieci (Marszałek, 2013, s. 18). Według Marszałek komponentami duchowości dziecka w wieku przedszkolnym są: świadomość, rozumność i mądrość, miłość, moralność, twórczość, wrażliwość estetyczna, religijność, transgresja (tamże). Wydaje się, że we wczesnoszkolnej edukacji, gdy dzieci w ciągu trzech lat dynamicznie wchodzą $\mathrm{w}$ świat wiedzy i nabierają kompetencji do jego rozpoznawania oraz przygotowują się do pokonywania formalizmu w zachowaniach, to można na tym etapie uwzględnić także światopogląd w jego zaczątkowej fazie i na pewno wiarę, której rozwój obok formalnej religijności nabiera szczególnego znaczenia, bowiem ten okres przeznaczony jest na przygotowanie katolickich dzieci do pierwszej Komunii świętej (Kulpaczyński, 2009).

Tak dochodzimy do ważnego elementu organizacyjnego procesu edukacji szkolnej, jaki stanowi organizacja lekcji religii, czyli katecheza. Religia obecna w szkole od 1991 r., po upadku komunistycznej dyktatury (także w oświacie), stwarza szansę w pełni integralnego rozwoju i wychowania ucznia, zgodnie z jego przekonaniami, ze światopoglądem rodziców. Ten rodzaj organizacji procesu edukacji szkolnej, w tym wczesnoszkolnej, nie narusza godności i duchowości kogokolwiek, wręcz przeciwnie, umożliwia uczenie się i doświadczanie autentycznej tolerancji, przygotowuje do akceptacji innych, bez względu na ich wyznanie czy poglądy, kształtuje postawy konieczne do pokojowego życia w pluralistycznym społeczeństwie. We wczesnoszkolnej edukacji, gdy zasadnicza przestrzeń szkolna zamknięta jest w jednej klasie, to dekoracje związane z kulturą religijną, okresowymi świętami, typowymi w polskiej tradycji, nie tylko powinny znaleźć swoje miejsce, lecz wyjaśnienie ich znaczenia może stanowić okazję do 
rozpoznania polskich tradycji i zwyczajów, pouczającego dla każdego ucznia, bez względu na jego przekonania. Trzeba zauważyć, że w systemie dydaktyczno-wychowawczym M. Montessori, mimo że nie formułuje się „konkretnych celów i treści w zakresie wychowania duchowego, światopoglądowego oraz religijnego" (Buk-Cegiełka, 2013, s. 116), to jednak postuluje się zorganizowanie w klasie kącika religijnego z obrazkami, figurami, książeczkami czy prasą religijną do dowolnego wykorzystania. Jak świat zewnętrzny, tak izba klasowa może się stać przestrzenią zróżnicowanych elementów, pośród których uczeń ma szansę kształtować swoją duchowość, szanując godność każdego i rozumiejąc, że bliźni może inaczej postrzegać to, co ważne i najważniejsze w życiu.

Z pewnością katecheza i z nią związana wiara należą do istotnych czynników kształtujących duchowość dzieci we wczesnoszkolnej edukacji, ale ich nie wyczerpują. Z dotychczasowych analiz wynika, szczególnie pod wpływem myśli S. Kunowskiego, P. Sochy i L. Marszałek, że do komponentów duchowości, które może i powinna stymulować wczesnoszkolna edukacja należą:

- samoświadomość - odkrywanie własnego Ja, wiedzy o sobie samym, kształtowanie własnej tożsamości, odkrywanie swojej ograniczoności i przemijania;

- rozumność i mądrość - rozumienie zjawisk prostych i coraz bardziej złożonych, rozumienie świata, siebie, innych, próby abstrakcyjnego myślenia, budowanie mądrości jako wiedzy i zdolności do formułowania tez, hipotez, sądów o biegu ludzkiego życia, odkrywanie sensu zjawisk i życia;

- miłość - poznawanie uczuć, ich wyrażanie i kierowanie nimi, odkrycie piękna i sensu miłości do bliźnich, do Najwyższych Wartości, pielęgnowanie przyjaźni, radość kochania i przebaczania we własnym środowisku - szkolnym, rodzinnym, koleżeńskim;

- moralność - zdolność do wartościowania i oceniania, do rozróżniania dobra i zła, kształtowanie sumienia, umiejętność korzystania z wolności - do tworzenia dobra, kierowanie się prawdą, rozumienie odpowiedzialności za własne wybory, zachowania i czyny, początki budowania autonomii moralnej;

- twórczość - zdolność innowacyjna w różnych dziedzinach, do wnoszenia czegoś nowego w myślenie, organizowanie, działanie nie tylko kulturowe, artystyczne, lecz także społeczne, emocjonalne, sprawnościowe, intelektualne, religijne; odkrywanie własnych możliwości twórczych;

- wrażliwość estetyczna - gust i jego przemiany, spostrzegawczość i wyczucie piękna, zachwyt i kontemplacja nad różnorodnym pięknem, kształtowanie piękna w różnych dziedzinach artystycznych i we własnym środowisku życia; 
- światopogląd - otwartość na głębię metafizyczną - stawianie pytań o ostateczną miarę i sens rzeczywistości, budowanie zaczątków światopoglądowych obrazu świata, systemu wartości - ich preferencji, zespołu własnych poglądów i przekonań;

- religijność - aktywność obrzędowa, zespół zachowań religijnych, elementy wiedzy religijnej i ich rozumienie, przeżycia religijne;

- wiara - naturalna jest zawierzeniem komuś czy czemuś, przyjęciem czegoś za prawdę, religijna wiara jest transcendencją ku Osobie Boga, więzią osobową, podtrzymywaną praktyką religijną (modlitwy, Msze św., nabożeństwa), wymagającą też wiedzy i rozumienia (katecheza).

Oprócz powyższych komponentów, L. Marszałek (2013, s. 257-275) w odniesieniu do dzieci przedszkolnych wprowadza jeszcze transgresję polegającą na przekraczaniu granic, mającym swoje konotacje konstruktywne, jak i destruktywne. Podobnie, jak transcendowanie czy transcendencja rozumiana czasownikowo, stanowiąca istotną cechę ludzkiego potencjału i ludzkiej aktywności, tak transgresja jest ważnym dynamizmem duchowym, będącym u podstaw duchowości i jej różnych komponentów.

Ogólna analiza porównawcza między powyższymi komponentami a podstawą programową wczesnoszkolnej edukacji umożliwia sformułowanie następujących wniosków:

- w ogólnym wprowadzeniu do podstawy programowej dla szkoły podstawowej zarysowany jest jeden z celów, który polega na „odkrywaniu przez ucznia własnych możliwości, sensu działania oraz gromadzenia doświadczeń na drodze prowadzącej do prawdy, dobra i piękna" (Podstawa programowa, 2017, s. 16 w Dz. U.) - koresponduje on z takimi elementami duchowości, jak: rozumność i mądrość, miłość, moralność, twórczość, wrażliwość estetyczna, światopogląd;

- we wprowadzeniu do zadań szkoły na uwagę zasługuje zadanie nr 3 (wspieranie aktywności intelektualnej i twórczej uczniów), zadanie nr 5 (wspieranie indywidualności i oryginalności), zadnie $\mathrm{nr} 7$ (poznawanie wartości i norm społecznych, kultury narodowej i innych krajów) - zadania te współgrają z takimi komponentami duchowości, jak rozumienie i mądrość, twórczość, wrażliwość estetyczna;

- w celach kształcenia - wymaganiach ogólnych istotny jest cały punkt drugi, poświęcony osiągnięciom uczniów w zakresie emocjonalnym; punkt trzeci dotyczący zakresu społecznego; punkt czwarty, odnoszący się do obszaru poznawczego - co odpowiada takim komponentom duchowym, jakim jest miłość, samoświadomość, rozumność i mądrość, światopogląd, moralność, a nawet twórczość; 
- w treściach nauczania - wymaganiach szczegółowych, w których opisano efekty w zakresie trzynastu modułów edukacyjnych - można odnaleźć odniesienie do następujących komponentów duchowości: samoświadomość, rozumność i mądrość, miłość, moralność, twórczość, wrażliwość estetyczna, niewiele efektów dla światopoglądu, jeden dla religijności.

Należy podkreślić, że wiele szczegółowych treści i wskazanych efektów w edukacji wczesnoszkolnej jest kompatybilnych z komponentami duchowości, jaką powinni uczniowie rozwijać w swoim wieku. Jedynie komponent wiary nie odnalazł się nigdzie, a religijność tylko w module etyki. Można stwierdzić, że realizowana edukacja wczesnoszkolna, kształtowana na aktualnej podstawie programowej, sprzyja rozwojowi duchowości typu naturalistycznego, którą dopełnia obecność religii w systemie szkolnym, powodująca rozwój duchowości uczniów - typu religijnego.

Edukacja szkolna ma niezwykle ważne i odpowiedzialne zadanie, którym jest wspieranie integralnego rozwoju ucznia poprzez odpowiedni system kształcenia i wychowania. Integralny rozwój zakłada całościowy, pełny, harmonijny rozwój osobowy ucznia w sferze fizycznej, psychicznej, społecznej, kulturowej i duchowej. Każda sfera ma swoje znaczenie, ale duchowa nadaje kierunek życiu i decyduje o jakości funkcjonowania osobowego. Nigdy nie może być pomijana. W edukacji wczesnoszkolnej podstawa programowa stwarza warunki do rozwoju duchowości typu naturalistycznego, ale jest w tym zakresie mało dynamiczna. Możliwe, że powód stanowi zbytnie skoncentrowanie się na czterech tylko sferach oddziaływania edukacyjnego: fizycznym, emocjonalnym, społecznym, poznawczym (Podstawa programowa, 2017, s. 31-33 w Dz. U.), które nie wyczerpują kryterium integralnego rozwoju i wychowania ucznia. Wydaje się, że potrzebna jest optymalizacja podstawy programowej i wyeksponowanie elementów kulturowych, moralnych, duchowych. Ta optymalizacja powinna objąć antropologiczny wymiar procesu edukacji, który w podstawie znalazłby odzwierciedlenie w klarownym określeniu wizji ucznia jako osoby, wizji personalistycznej, stanowiącej punkt wyjścia dla adekwatnych, integralnych programów edukacji, w tym edukacji wczesnoszkolnej. 


\section{BIBLIOGRAFIA}

BuK-CEGIEŁKA, M. (2013). Integralny rozwój i wychowanie dziecka w systemie wychowawczo-dydaktycznym Marii Montessori. Elementy teorii i praktyki. Lublin: Libropolis.

ChaŁAs, K. (2007). Wychowanie ku wartościom wiejskim jako szansa integralnego rozwoju wychowanka. Lublin: KUL.

Chmielewski, M. (2002). Duchowość. W: M. ChMIELEwSKI (red.), Leksykon duchowości katolickiej, Lublin-Kraków: Wydawnictwo M.

JAN PAWEE II (1994). List do rodzin.

JusiaK, R. (2016). Duchowość chrześcijańska. W: K. ChaŁAS, A. MAJ (red.), Encyklopedia aksjologii pedagogicznej. Radom: POLWEN.

KARBOwnicZEK, J., KLim-KLimASZEWSKA, A. (2016). Edukacja wczesnoszkolna w teorii i praktyce. Kraków: WAM.

KUlPACZYŃSKI S. (2009). Psychologia rozwojowo-wychowawcza nie tylko dla katechetów. Lublin: Polihymnia.

Kunowski, S. (2004). Podstawy wspótczesnej pedagogiki. Warszawa: Wydawnictwo Salezjańskie.

MarszaŁeK, L. (2013). Duchowość dziecka. Znaczenia - perspektywy - konteksty w pedagogice przedszkolnej. Warszawa: Szkoła Wyższa im. Bogdana Jańskiego.

Milerski, B., Śliwerski, B. (red.) (2000). Leksykon PWN. Pedagogika. Warszawa: PWN.

MurawsKA, B. (2014). Edukacja wczesnoszkolna. Warszawa: Instytut Badań Edukacyjnych.

NowaK, M. (2008). Teorie $i$ koncepcje wychowania. Warszawa: Wydawnictwo Akademickie i Profesjonalne.

OstRowsKa, K. (1994). W poszukiwaniu wartości. Gdańsk: Rubikon.

Podstawa programowa kształcenia ogólnego dla szkoły podstawowej (2017). Załącznik nr 2 do Rozporządzenia MEN z dnia 14 lutego 2017 r. w sprawie podstawy programowej wychowania przedszkolnego oraz podstawy programowej kształcenia ogólnego dla szkoły podstawowej, w tym dla uczniów z niepełnosprawnością intelektualną w stopniu umiarkowanym lub znacznym, kształcenia ogólnego dla branżowej szkoły I stopnia, kształcenia ogólnego dla szkoły specjalnej przysposabiającej do pracy oraz kształcenia ogólnego dla szkoły policealnej. Dz. U. 2017, poz. 356.

POPIELSKI, K. (2004). Noo-logoterapia. Elementy wprowadzenia. Lublin-Kielce: ŚCPiE.

RYNIO, A. (2004). Integralne wychowanie w myśli Jana Pawta II. Lublin: Wydawnictwo KUL.

SochA, P. (2000). Psychologia rozwoju duchowego - zarys zagadnienia. W: P. SochA (red.), Duchowy rozwój człowieka. Fazy życia, osobowość, wiara, religijność. Kraków: Wydawnictwo Uniwersytetu Jagiellońskiego.

\section{DUCHOWOŚĆ W INTEGRALNEJ EDUKACJI WCZESNOSZKOLNEJ}

\section{Streszczenie}

Podstawa programowa i organizacja procesu edukacji implikuje możliwość realizacji edukacji wczesnoszkolnej jako integralnej, która wiąże się z rozwojem ucznia w zakresie psychofizycznym, społecznym, kulturowym, nie wykluczając duchowego. Duchowość, rozumiana naturalistycznie czy religijnie (w ujęciu chrześcijańskim), wiąże ze sobą takie kategorie, jak sens (sens ostateczny), wartości (najwyższe, ostateczne), doskonałość moralna, świętość. Duchowy rozwój dzieci w okresie wczesnoszkolnej edukacji stanowi ważną fazę w ich rozwoju integralnym, zmierzającym ku dojrzałości osobowościowej zintegrowanej z dojrzałością duchową, dojrzałością religijną.

Słowa kluczowe: edukacja wczesnoszkolna; integralny rozwój i wychowanie; duchowość. 


\section{SPIRITUALITY IN INTEGRAL EARLY SCHOOL EDUCATION}

\section{S u m m a r y}

Programme basis and organisation of the education process implies the possibility of implementing early school education as an integral one, which is connected with the student's development in the psychophysical, social and cultural spheres, not excluding the spiritual one. Spirituality understood naturalistically or religiously (in Christian terms) binds such categories as sense (ultimate sense), values (highest, ultimate), moral perfection, and sanctity. The spiritual development of children during early school education is an important phase in their integral development, aimed at personality maturity integrated with spiritual maturity and religious maturity.

Key words: early school education; integral development and upbringing; spiritual. 